Prethodno priopćenje

Primljen: 12. ožujka 2021.

izv. prof. dr. sc. Dunja Anđić

Prihvaćen: 14. svibnja 2021.

Učiteljski fakultet Sveučilišta u Rijeci

Katedra za metodike nastavnih predmeta prirodnih i društvenih znanosti dunja.andic@uniri.hr

Karmen Vidas, mag. prim. educ.

Osnovna škola Ivana Rabljanina, Rab

karmen.vidas@skole.hr

\title{
ISTRAŽIVAČKI PRISTUP KAO SUVREMENA NASTAVA ILI TEK ODMAK OD TRADICIONALNE NASTAVE? MIŠLJENJA UČITELJA O ISTRAŽIVAČKOM PRISTUPU U NASTAVI PRIRODE I DRUŠTVA
}

Sažetak: Istraživački pristup u nastavi Prirode i društva smatra se novim pristupom u učenju i poučavanju u osnovnoj školi. Međutim, pitamo se je li to doista tako. Zato je provedeno istraživanje s ciljem ispitivanja odgojno-obrazovne prakse učitelja razredne nastave u realizaciji istraživačkog pristupa u nastavi Prirode i društva. Istraživanje je provedeno kvalitativnom metodologijom na uzorku 24 učitelja razredne nastave u osnovnim školama. Za potrebe istraživanja konstruiran je polustrukturiran intervju. Rezultati istraživanja uputili su na upoznatost učitelja s istraživačkim pristupom i njihovu motiviranost za njegovo provođenje u nastavi Prirode i društva. Dobiveni su rezultati također uputili na to da učitelji u velikoj mjeri smatraju da posjeduju određene kompetencije za njegovu implementaciju, a prilikom realizacije primjenjuju nastavne metode $i$ nastavne oblike rada koji omogućuju veću aktivnost učenika. Zaključuje se da je potrebno dodatno educirati učitelje jer, iako je riječ o suvremenom pristupu, njegova realizacija još uvijek nije na očekivano zadovoljavajućoj razini i stoga on predstavlja tek prvi korak ka suvremenijoj nastavi u školama.

Ključne riječi: istraživački pristup, kompetencije, kurikul, motivacija, odgojno-obrazovna praksa 


\section{UVOD}

Nastavni kurikul Prirode i društva, prema Odluci o donošenju kurikuluma za nastavni predmet Prirode i društva za osnovne škole u Republici Hrvatskoj (Narodne novine, 7/2019-147), počinje se provoditi školske godine 2019./2020. i to za učenike prvoga razreda. Priroda i društvo u njemu se definira kao interdisciplinaran nastavni predmet koji povezuje znanstvene spoznaje više različitih područja, kao što su prirodoslovno, društveno-humanističko i tehničko-informatičko, te kao predmet koji učenika uvodi u istraživanje i spoznavanje svijeta koji ga okružuje. Uz prirodoslovnu i društveno-humanističku sferu, u procesu učenja i poučavanja Prirode i društva, a u skladu s novim suvremenim zahtjevima, nastavni predmet uključuje i tehničko-informatičko područje koje učeniku omogućuje pravilnu upotrebu različitih oblika informacijsko-komunikacijske tehnologije u procesu stjecanja znanja, razvijanja sposobnosti i vještina te zauzimanja stavova (Ministarstvo znanosti i obrazovanja (MZO); Kurikulum nastavnog predmeta Priroda i društvo za osnovne škole, 2019). Novi dokument u hrvatskom odgojno-obrazovnom sustavu Kurikulum nastavnog predmeta Priroda i društvo za osnovne škole 2019. godine donosi novi suvremeniji pristup učenju i poučavanju nastavnog predmeta Priroda i društvo. Taj suvremeniji pristup odnosi se na uključivanje istraživačkog pristupa u nastavu Prirode i društva koji se temelji na istraživačkim aktivnostima učenika mlađe školske dobi. Iako se o potrebi uključivanja istraživačkog pristupa govori već godinama, cjelovita reforma hrvatskog obrazovanja konačno dovodi do njegova uključivanja u nastavni proces. Brojna istraživanja pokazala su pozitivne učinke korištenja istraživačkog pristupa u nastavi, ali i određene nedostatke. Budući da se istraživački pristup u nastavi Prirode i društva u hrvatskim školama počinje službeno primjenjivati tek odnedavno, cilj ovog rada bio je ispitati odgojno-obrazovnu praksu učitelja razredne nastave $u$ realizaciji istraživačkog pristupa u nastavi Prirode i društva, što uključuje njihovo poznavanje istraživačkog pristupa, kompetencije i motivaciju za pripremu i realizaciju istraživačkog pristupa, učestalost provođenja te nastavne oblike rada i nastavne metode kojima se pritom koriste.

\section{ISTRAŽIVAČKI PRISTUP U UČENJU I POUČAVANJU}

Kurikulumom nastavnog predmeta Priroda i društvo za osnovne škole (2019) naglašeno je stjecanje kompetencija važnih za cjelokupan život učenika koje se stječu povezivanjem učenja s vlastitim iskustvima učenika te njegovim aktivnim sudjelovanjem u nastavnom procesu. Kurikul obuhvaća četiri temeljna koncepta: Organiziranost svijeta oko nas, Promjene $i$ odnosi, Pojedinac $i$ društvo i Energija. Tijekom nastave Prirode i društva temeljni koncepti međusobno se isprepliću i dograđuju, a u procesu učenja i poučavanja ističe se metodološki pristup nazvan istraživački pristup koji zadovoljava ljudsku potrebu za 
istraživanjem svijeta koji nas okružuje (MZO, Kurikulum nastavnog predmeta Priroda i društvo za osnovne škole, 2019). Nadalje, u Kurikulu se ističe potreba ljudske prirode za istraživanjem i otkrivanjem uzročno-posljedičnih veza u Prirodi i društvu koje ga okružuju. Istraživačko učenje čini niz aktivnosti u kojima učenici razmišljaju kritički i analitički kako bi tražili i konačno pronašli vlastiti odgovor na problem. Takav pristup izgrađen je na pretpostavci da ljudi imaju urođenu potrebu za istraživanjem i pronalaženjem vlastitog znanja (Sanjaya, 2006, prema Septi Andrini, 2016). Prema tome, zadatak nastavnog predmeta jest zadovoljavanje tih potreba. „Istraživačkim pristupom učenik razvija vještine koje će kasnije primijeniti i u svakodnevnome životu te na temelju kritičkoga razmatranja valjanih dokaza i argumenata donositi relevantne odluke. Istraživački pristup pridonosi razvijanju znatiželje, kreativnosti, vještina promatranja, uspoređivanja, razvrstavanja, postavljanja pitanja, predviđanja, analiziranja, generaliziranja, vrednovanja, komuniciranja, prikupljanja informacija i slično" (MZO, Kurikulum nastavnog predmeta Priroda i društvo za osnovne škole, 2019, str. 8). Ovaj pristup učenicima omogućuje sustavno stjecanje temeljnih vrijednosti, znanja i vještina koji će im biti potrebni u svakodnevnome životu. Uključivanjem istraživačkog pristupa u nastavu već od prvoga razreda, učenici se privikavaju na drugačiji i zanimljiviji način rada koji dovodi do ostvarivanja sve više ishoda učenja. Ovakav pristup učenju omogućava učenicima pronalaženje i rješavanje problema, a u procesu aktivnog učenja, učenici konstruiraju nove ideje ili koncepte na temelju prijašnjih znanja i iskustava (Septi Andrini, 2016). U procesu učenja iskustvo učenika ima važnu ulogu. Povezivanjem sadržaja s prijašnjim iskustvima učenici mogu bolje razumjeti sadržaj te ga dograditi novim znanjima. Uključivanje istraživačkog pristupa u nastavu prvi je korak u uključivanju učenika u znanstveno obrazovanje, a definiran je kao ključan koncept osnovnog znanstvenog obrazovanja (Harlen, 2009, prema Löfgren i sur., 2013). Znanstveno obrazovanje jedan je od zahtjeva suvremenog društva i uključivanja u aktivan život zajednice. U istraživačkom pristupu učenje je aktivno, a temelji se na istraživanju, odnosno raznim istraživačkim modelima $i$ istraživačkim aktivnostima. Naglasak je na oblicima rada u kojima se učenicima prezentira izazov koji može biti odgovaranje na postavljeno pitanje, opažanje i objašnjavanje neke pojave, interpretacija ili testiranje hipoteza. U procesu rješavanja izazova učenici ostvaruju cilj, a to je učenje (Princ i Felder, 2007). Vodeći se induktivnim načinom poučavanja, izazov se ostvaruje istraživanjem, a ne prenošenjem gotovih činjenica. Princ i Felder (2007) naglašavaju da informacije potrebne za odgovaranje na postavljeni izazov ne bi smjele biti prethodno teorijski izrečene jer je cilj samostalno zaključivanje. Pritom se nove informacije trebaju dograđivati na otprije poznat sadržaj (Princ i Felder, 2007). Istraživački pristup u poučavanju učinkovitiji je od tradicionalnog poučavanja „gotovih“ činjenica. Osim toga, utječe na razvoj mišljenja i rješavanja problema, motivaciju te dovodi do ostvarenja boljih 
akademskih postignuća učenika (Princ i Felder, 2007). Mišljenje i motivacija razvijaju se u procesu, a to u konačnici dovodi do ostvarenja odgojno-obrazovnih postignuća, odnosno ishoda učenja. Važno je naglasiti da se nakon stupanja na snagu Kurikuluma nastavnog predmeta Priroda i društvo za osnovne škole (2019) više ne govori o odgojno-obrazovnim postignućima učenika kao što je to bio slučaj u Nastavnom planu i programu (2006), već o ishodima učenja koji se ostvaruju svakom nastavnom jedinicom. Također je naglašeno kako je realizaciju istraživačkih aktivnosti preporučljivo povezivati sa situacijama bliskim učenicima, a da one pritom budu dovoljno izazovne kako bi došlo do razvoja učeničkih vještina (Colburn, 2006, prema Princ i Felder, 2007). Potreba povezivanja s bliskim situacijama naglašava se i nastavnim načelima zavičajnosti ili zavičajne blizine, sistematičnosti i postupnosti. Prema Bayram i suradnicima (2013), učenici su stavljeni pred izazov, prepoznaju osnovni problem koji moraju riješiti, prikupljaju podatke koji će im pomoći u pronalasku rješenja, testiraju hipoteze i izvode zaključke analiziranjem dobivenih podataka (Domin, 1999, prema Bayram i sur., 2013). U tom slučaju, učenici zauzimaju aktivnu ulogu u procesu dolaska do rješenja postavljenih problema (Hodson, 1990, prema Bayram i sur., 2013).

Löfgren i suradnici (2013) ističu važne metode poučavanja u istraživački usmjerenoj nastavi. Autori navode da metode temeljene na istraživanju od najranije dobi potiču učenike na kritički stav i raspravu te naglašavaju važnost praktičnog rada čime utječu na razvoj znanstvenog razmišljanja (Crawford, 1997, prema Löfgren i sur., 2013). Učenici koji sudjeluju u istraživačkim aktivnostima često su motivirani za učenje i razvijaju pozitivan stav prema učenju, što je i cilj istraživačkog pristupa. Osim toga, cilj je i stvaranje poticajnog okruženja za učenje s razumijevanjem (Brown, 2000, prema Löfgren i sur., 2013). Razvijanje pozitivnih stavova omogućit će samoregulirano učenje učenika koji će, potaknuti svojom unutarnjom motivacijom, rado učiti i težiti cjeloživotnom učenju.

Harlen i Allende (2006) detaljno se bave istraživačkim pristupom u nastavi, što u nastavku podrobnije pojašnjavamo. Autori navode da istraživački pristup obuhvaća iskustva koja učenicima omogućuju razumijevanje znanstvenih aspekta svijeta oko sebe. Znanstveno obrazovanje utemeljeno na istraživanju obuhvaća iskustva koja omogućuju učenicima razvoj razumijevanja i spoznavanje znanstvenih spoznaja u svijetu oko sebe i to korištenjem istraživačkih vještina. Također, autori navode i temeljne istraživačke vještine, a to su opažanje, postavljanje pitanja, proučavanje knjiga i ostalih izvora informacija, planiranje istraživanja, pregled poznatog sadržaja, korištenje alata, analiziranje i interpretiranje podataka, predlaganje odgovora, objašnjavanje, predviđanje i prezentiranje rezultata (Harlen i Allende, 2006). Iz navedenog može se zaključiti da se vještine koje zagovara istraživački pristup ne razlikuju od vještina potrebnih za provođenje znanstvenih istraživanja. Prema tome, uvođenje istraživačkog 
pristupa u osnovnoškolsko obrazovanje znači postavljanje temelja za znanstveno obrazovanje svih učenika. Autori naglašavaju i činjenicu da se navedene vještine ne upotrebljavaju zajedno svaki put. Drugim riječima, koriste se one vještine koje zahtijeva neka nastavna cjelina i koje će u tom slučaju biti svrhovite. Osim toga, važno je da se pritom ostvari cilj, a to je razvijanje razumijevanja (Harlen i Allende, 2006). Autori (2006, str. 12) također postavljaju pitanje: Što je važno u procesu učenja? To je pitanje koje si i učenici često postavljaju. Svi sudionici nastavnog procesa, pa tako i učenici, trebaju biti upoznati s time što je važno u cjelokupnom procesu učenja. Prvotno, trebaju biti svjesni činjenice da zapamćivanje pojmova iz udžbenika ili prenesenih predavanjima učitelja, bez njihova dubljeg razumijevanja, nije cilj procesa učenja. Bez obzira na to, učenici trebaju usvojiti velike količine znanja za život u svijetu koji se mijenja i postaje sve više tehnološki i znanstveno napredniji. Učenici trebaju naučiti organizirati i regulirati vlastito učenje i prevladavati poteškoće u tom procesu (Harlen i Allende, 2006, str. 12) i tako steći određene preduvjete za uspješno učenje u budućnosti. Harlen i Allende (2006) važnost vide u konceptu učiti kako učiti, čime naglasak stavljaju na metakognitivne vještine i samoregulirano učenje. Tako ga određuju važnom komponentom razvoja kompetencija cjeloživotnog učenja. Autori također ističu važnost razvijanja ideja. Kako navode, učenik će eliminirati neke od ideja u razgovoru s drugima zbog različitih iskustava sudionika nastavnog procesa, a neke će zahtijevati traženje dodatnih informacija. Autori dodaju i mogućnost traženja alternativnih ideja ako se dokazi koje je učenik prikupio ne slažu s njegovim predviđanjima i ne podržavaju postavljenu hipotezu. U konačnici, autori cijeli proces razvijanja ideja i promišljanja o njima objašnjavaju kao velik doprinos u procesu učenja i jedno od važnijih iskustava učenja (Harlen i Allende, 2006). Isti autori u obrazlaganju procesa postavljaju pitanje zbog čega je važno započeti s istraživačkim pristupom već u najranijem stupnju obrazovanja. Prema njihovu mišljenju, uvođenje istraživačkog pristupa razvija razumijevanje, istraživačke vještine te sposobnosti zauzimanja stavova kod učenika. Kao ključne istraživačke aktivnosti učenika u osnovnoj školi navode: prikupljanje podataka promatranjem stvarnih događaja ili korištenjem drugih izvora, rad na pitanjima koja su si postavili učenici ili pitanjima koja je postavio učitelj, postavljanje dodatnih pitanja, postavljanje predviđanja na temelju onoga što pronalaze, međusobni razgovori i razgovori $\mathrm{s}$ učiteljem o tome što promatraju ili istražuju, izražavanje s razumijevanjem i korištenjem odgovarajućih pojmova, predlaganje načina testiranja vlastitih i tuđih ideja kako bi se moglo ustvrditi postojanje dokaza koji podržavaju te ideje, sudjelovanje u planiranju istraživanja da bi se odgovorilo na konkretna pitanja, korištenje mjernih instrumenata i ostale opreme na odgovarajući način, pokušaji rješavanja problema, korištenje raznih izvora informacija radi sakupljanja činjenica potrebnih za njihovo istraživanje, procjenjivanje valjanosti i korisnosti različitih ideja u odnosu na dokaze, razmatranje ideja koje nisu njihove te 
kritičko osvrtanje na postupak i rezultate njihova istraživanja (IAP, 2006, prema Harlen i Allende, 2006, str. 15). Na temelju toga moguće je zaključiti da se istraživačkim pristupom uvelike doprinosi razvoju različitih učeničkih vještina. Sve navedene vještine podrazumijevaju da učenici u nastavnom procesu zauzimaju aktivnu ulogu i u velikoj mjeri sudjeluju u nastavnom procesu.

Istraživački pristup u osnovnoškolskom obrazovanju još je uvijek nedovoljno zastupljen, o čemu govore pojedina istraživanja (Alagić, 2021; Anđić i sur., 2020; Letina, 2016). Kako bi obrazovanje postalo učinkovito, a obrazovni sustav pripremio nove generacije na život u sve naprednijem svijetu, potrebna je promjena. Dobar način za to priprema je od najranije dobi, odnosno izlaganje učenika obrazovnom modelu u kojemu će i oni biti dio nastavnog procesa. Informacije koje su konstruirane da bi zadovoljile dječju znatiželju potrebno je dopunjavati ili pojašnjavati, a upravo to je zadatak obrazovnog sustava. Pritom se komunikacija između učitelja i učenika ne smije svesti na prijenos postojećih informacija u knjigama ili ostalim izvorima znanja. Takav način poučavanja utječe na smanjenje motivacije kod učenika, a takav nastavni sat ostavlja loš dojam na učenike, gasi znatiželju i udaljava učenike od sadržaja koji možda i jesu u polju njihova interesa. Da bi se to spriječilo, potrebno je nastavu učiniti što zanimljivijom učenicima, a to je moguće postići korištenjem istraživačkog pristupa u nastavi, osobito u nastavi Prirode i društva. Učitelj pritom treba biti onaj koji će poticati dječju znatiželju, usmjeravati učenike i pomoći im u razvijanju vještina eksperimentiranja kako bi samostalno mogli razjasniti sumnje i to eksperimentima s jednostavnim i dobro strukturiranim nastavnim materijalims koji će olakšati nastavu i dovesti do ostvarenja očekivanih ishoda učenja. Iako $\mathrm{u}$ istraživačkom pristupu učenici sve više samostalno rade, a učitelj je u tom slučaju moderator, njegova je uloga također vrlo važna.

\section{ISTRAŽIVAČKI PRISTUP KAO PRVI KORAK KA SUVREMENOJ NASTAVI}

Uključivanje istraživačkog pristupa smatra se jednim od osnovnih zahtjeva suvremene nastave. Stoga se pitamo je li istraživački pristup samo prvi korak ka odmaku od tradicionalne nastave ili podrazumijeva suvremeni pristup. Dosadašnja istraživanja upućuju na to da su istraživački oblici rada, kao oblik aktivnog učenja unutar pedagogijskih koncepata, postojali još u vrijeme slobodnih škola, alternativnih i reformskih pravaca J. Deweya, Freineta, teorija Piageta i Vygotskog pa se nadalje razvijali do suvremenih istraživačkih modela poput modela Banchija i Bella (2008), Milneova modela (2010) i dr. Istraživački oblici rada u učenju i poučavanju stoga nisu novina, već su postojali i ranije. Međutim, u kontekstu uvođenja ovog pristupa u nastavu Prirode i društva možemo zaključiti da su oni tek prvi korak ka suvremenoj nastavi, o čemu govore i drugi autori. Prema Perković Krijan (2016, str. 1) „Istraživačka 
nastava Prirode i društva jedan je od odgovora na potrebe suvremene škole jer su brojna istraživanja potvrdila njezine pozitivne učinke...", uz isticanje činjenice da je istraživački pristup učenju i poučavanju dio velikog broja europskih i svjetskih suvremenih kurikula. Ista autorica argumentirano pojašnjava terminološku nejasnoću pojmova vezanih za istraživačku nastavu, ali daje i detaljan povijesni pregled ovog pristupa, oblika i metoda rada navodeći njegovu nedostatnu terminološku usklađenost i određenost. Stoga se postavlja pitanje što ga čini suvremenim. Prema Perković Krijan i sur. (2017), brojna istraživanja dokazala su njegov učinak na učenikova postignuća, socijalizaciju, unaprjeđivanje prirodoznanstvene pismenosti i dr. Bitno obilježje ovog pristupa jest konstruktivistički pristup učenju i poučavanju uz naglašeno pozicioniranje učenika kao aktivnog istraživača, a ne pasivnog primatelja, čime se odmiče od tradicionalnih oblika učenja i poučavanja (Perković Krijan, 2016) i postavljaju temelji, odnosno čine prvi koraci ka suvremenoj nastavi.

Uključivanjem istraživačkog pristupa u nastavu učenike se stavlja pred izazov koji se izazov ostvaruje istraživanjem, proučavanjem, uočavanjem i povezivanjem pojava i procesa unutar Prirode i društva. Mijenjanjem i napredovanjem nastavnog procesa ostvaruje se raznolikost, čime cijeli proces učenicima postaje zanimljiv, što dovodi do razvoja zadovoljstva, kreativnosti i stvaralaštva, a time se ostvaruju i suvremeni kurikulni pristupi. Ovakav novi oblik poučavanja i učenja odmiče od tradicionalnog i uvodi nas u suvremeni oblik nastavnog procesa usmjerenog na učenika i njegov cjelokupni razvitak (Boras, 2009). „Ponuđeni sadržaji ‘pozivaju’ učenike da iskuse bogatstvo svijeta, da tragaju za vlastitim odgovorima, izazivajući ih tako da razumiju složenost procesa čovjek-priroda-društvo“" (Boras, 2009, str. 46). Sadržaji predmeta Priroda i društvo već su zanimljivi učenicima koji posjeduju znatiželju za prirodu oko sebe. Učenicima je potrebno omogućiti povezivanje s prirodom i zato se poučavanje sadržaja Prirode i društva ne smije svesti na isključivo predavačku nastavu.

Kako bi se postigli odgojno-obrazovni ciljevi nastave Prirode i društva zadani novim kurikulom, potrebno je poduzeti određene korake. Jedan od njih je buđenje motivacije kod učenika stvaranjem pozitivnog okruženja za učenje u kombinaciji s izazovnim aktivnostima koje će kod učenika poticati znatiželju i želju za učenjem i otkrivanjem. „Kada je učenik motiviran, spreman je primiti podatke ili informacije koje će, kada se povežu s drugim relevantnim asocijacijama, stvoriti značenje i oblikovati ono što se zove učenje“" (Jensen, 2003, prema Boras, 2009, str. 41). Važnost motivacije u nastavnom procesu neosporna je. Motivacija je potrebna svima, a osobito učenicima koji vrlo često zauzimaju negativne stavove prema učenju. Kako ne bi došlo do razvoja negativnih osjećaja prema učenju, potrebno je više pozornosti posvetiti motiviranju učenika. Učenik treba biti motiviran kako bi bio spreman aktivno usvajati nastavne sadržaje. Zbog toga bi svaki nastavni sat trebao započeti motivacijom učenika. Ako 
kod učenika izostane motivacija, neće biti moguće ostvariti unaprijed zadane ishode. Zbog nedostatka motivacije, učenici se učenju ne posvećuju istim entuzijazmom kao u slučaju kada su visoko motivirani. Kada su učenici motivirani, puno će lakše usvajati nastavni sadržaj, a njihovo će znanje biti dugotrajnije. Učenik će biti motiviran onda kada pokazuje interes za sadržaj i kada može aktivno sudjelovati u nastavnim aktivnostima. Prilikom motiviranja učenika važno je voditi računa o njihovim interesima. „U aktivnoj školi se polazi od zainteresiranosti djeteta. Cilj nastave je razvoj ličnosti i individualnosti djeteta. U takvoj školi se koriste aktivne metode učenja. Učenik istražuje, pita i uči učenje, a ocjenjuje se napredak, motiviranost, razvoj ličnosti, rad" (Omerović i Džaferagić-Franca, 2011, str. 173). Kvalitetnim izborom sadržaja, nastavnih metoda i oblika rada, usklađivanjem poučavanja i učenja s učeničkim sposobnostima i interesima, učenik postaje motiviraniji za učenje. Učenici tako stvaraju veze između postojećeg i novog znanja te iskustva dobivenog primjenom vlastitoga znanja u situacijama svakodnevnoga života (Kurikulum nastavnog predmeta Priroda i društvo za osnovne škole, 2019). Na motivaciju učenika utječe niz čimbenika na koje učitelj može utjecati. Odabirom učenicima zanimljivih sadržaja, odgovarajućih metoda i oblika rada kod učenika se može potaknuti želja za učenjem i napredovanjem. U tom procesu važno je da je učenik aktivan, odnosno da ima svoju ulogu u nastavnom procesu, a to je moguće postići istraživački usmjerenom nastavom koja odgovara suvremenim zahtjevima. Kako se navodi u Kurikulumu nastavnog predmeta Priroda i društvo za osnovne škole (2019, str. 6): „Iskustvena, istraživački usmjerena i problemska nastava u kojoj je učenik u središtu procesa učenja osigurava njegovu aktivnu ulogu u učenju i poučavanju“. Korištenjem istraživačkog pristupa izbjegava se pasivnost učenika, a stavljanje učenika u središte nastavnog procesa jedan je od glavnih ciljeva suvremene škole, čime se obogaćuje cjelokupna nastava, a nastavni sadržaji povezani su sa stvarnim životom učenika.

Mnogi autori navode nedostatke dosadašnjeg tradicionalnog načina poučavanja. Bognar i Matijević (2002) smatraju da ovakav oblik nastave nikako ne ide u prilog učenikovu znanju, kao ni razvoju njegovih vještina i sposobnosti. Zbog pasivnosti učenika u tradicionalnom obliku nastave, ne razvijaju se njegove vještine, kritičko razmišljanje i sposobnosti rješavanja problema (Bognar i Matijević, 2002). Prema Jensenu (2003), tradicionalna škola predstavlja instituciju u kojoj učenici postaju pasivni primatelji informacija koje učitelji dijele. Odmakom od tradicionalne nastave na površinu izlazi kvaliteta učenja i poučavanja koja potiče učenike na aktivno i sustavno učenje čime se razvijaju različite sposobnosti poput promatranja, prosuđivanja, kritičkog razmišljanja i izvođenja zaključaka (Števanić-Pavelić i Vlasac, 2006, str. 156). U suvremenom pristupu naglasak je na aktivnosti učenika koja dovodi do razvoja ne samo znanja, već i vještina i sposobnosti učenika. Bognar (2011) proveo je istraživanje $u$ kojem su vidljive razlike u tradicionalnoj nastavi usmjerenoj na sadržaje 
i suvremenoj nastavi usmjerenoj na učenika. Najvažnija je promjena korištenje metode aktivnog učenja gdje učenik prestaje biti pasivni sudionik nastavnog procesa (Bognar, 2011). Aktivno učenje još je jedan pojam koji vezujemo za suvremenu nastavu i istraživački pristup. Nikčević-Milković (2004) aktivno učenje podrazumijeva kao djelotvorno učenje, kritičko razmišljanje i stvaranje potrebe za učenjem kao cjeloživotnim obrazovanjem. Prema tome, ovakav oblik učenja zadovoljava potrebe suvremene škole, a njegovim uvođenjem moguće je ostvariti zadane ciljeve nastavnog predmeta. Aktivno učenje u literaturi se pojavljuje i kao sinonim za suvremeni pristup u kojem su učenici aktivni graditelji vlastita znanja. Prema tome, cilj nije usvajanje sadržaja, već učenje s razumijevanjem te povezivanje sa svakodnevnim životom čime se usvaja trajno znanje i stječu trajne vještine i sposobnosti za život (Lalović, 2009). Autori se slažu da tradicionalna nastava ne dovodi do napretka, već učenike sputava zbog njihove pasivnosti u nastavnom procesu. Rješenje vide u odmaku od tradicionalne nastave i usvajanju novih suvremenijih pristupa $u$ kojima će $u$ fokusu biti kvaliteta učenja, a ne količina zapamćenih činjenica. Pritom svaki učenik ima priliku biti aktivan sudionik koji svojom aktivnosti može doprinijeti nastavnom procesu, a u konačnici, izgradnjom vlastita identiteta, i cjelokupnom društvu. U tom procesu uloga je učitelja ključna.

\section{ULOGA UČITELJA U PROVOĐENJU ISTRAŽIVAČKOG PRISTUPA}

Uvođenjem istraživačkog pristupa uloga učitelja počinje se bitno razlikovati u odnosu na tradicionalnu nastavu. Prema Bognarovu istraživanju (2004), razvoj kreativnosti kod učenika uvelike ovisi o tome koliko su učitelji svjesni važnosti kreativnosti za djetetov razvoj. Autor piše da učitelji, kako bi potaknuli kreativnost, trebaju poznavati načine na koje u nastavnom procesu to mogu ostvariti. Učitelji trebaju biti spremni na mijenjanje tradicionalnih načina rada i uvođenje novih suvremenijih načina rada, kao što je istraživački pristup (Bognar, 2004). Prema već spomenutim autorima Harlenu i Allendeu (2006), važne aktivnosti učitelja prilikom provođenja istraživačkog pristupa u nastavi jesu: ,pružanje mogućnosti učenicima da se susretnu s materijalima i određenim pojavama kako bi ih mogli istražiti, organizacija rasprava o postupcima koji su planirani ili korišteni kako bi se otkrili načini na koji se može poboljšati pristup istraživanju, poticanje tolerancije, međusobnog poštovanja i objektivnosti i raspravama, omogućavanje pristupa alternativnim postupcima i idejama kroz raspravu, upućivanje na knjige i ostale izvore, postavljanje izazovnijih i složenijih zadataka uz pružanje podrške, kako bi učenici mogli iskusiti rad na naprednijoj razini, podučavanje tehnika potrebnih za napredovanje vještina, uključujući sigurnu uporabu opreme, poticanje učenika putem komentara $i$ ispitivanja na provjeru njihovih ideja, pružanje pomoći učenicima u snimanju 
njihovih opažanja, poticanje kritičkog razmišljanja te korištenje pitanja za poticanje istraživačkih vještina" (IAP 2006, prema Harlen i Allende, 2006, str. 15). Na temelju toga može se zaključiti da je uloga učitelja vrlo važna prilikom provođenja istraživačkog pristupa. Iako je u istraživačkom pristupu naglasak na što većoj aktivnosti učenika, učiteljeva aktivnost nikako nije zanemariva. Prema tome, učitelj svojim aktivnostima treba stvoriti povoljno okruženje za rad prilikom kojeg će učenici razvijati različite vještine i usvajati nova znanja. Pritchard i Woollard (2010) navode još neke od uloga učitelja. Prema njihovim promišljanjima, učitelj treba objasniti učenicima važnost sadržaja učenja, omogućiti im osjećaj kontrole vlastitog učenja, osigurati situacije aktivnog uključivanja, iskoristiti prethodna učenička iskustva, osmisliti iskustva učenja temeljena na razumijevanju kurikula, uključivati učenike dijalogom i postavljanjem pitanja, imati u vidu emocionalnu komponentu iskustva učenja i povezati aktivnosti s životnim primjerima (Pritchard i Woollard, 2010). Prema navedenom, uviđa se razlika s obzirom na ulogu učitelja u tradicionalnoj nastavi, koja se obično svodila na ulogu predavača. Löfgren i suradnici (2013) objašnjavaju izazov pred koji su stavljeni učitelji primarnog obrazovanja zbog činjenice da su znanstveni sadržaji u osnovnoškolskom obrazovanju najčešće opisnog karaktera. Autori zbog toga naglašavaju važnost uloge učitelja koja je ključna u kontekstu kvalitetnog poučavanja i učenja (Löfgren i sur., 2013). Prema tome, učitelj je odgovoran za odabir sadržaja i njihovu prilagodbu nastavnom satu na kojem učenici uče istraživačkim putem. To znači da učitelji trebaju odabrati odgovarajuće strategije za poučavanje sadržaja na što kvalitetniji način, što uključuje odabir načina, metoda i oblika rada, kao i nastavnih sredstva i pomagala, a sve to uz korištenje istraživačkog pristupa. Istraživački pristup ne može biti implementiran u učenje i poučavanje u osnovnoj školi ako se ne posjeduju dostatna znanja o njegovoj pripremi, planiranju i realizaciji u nastavi i ako učitelji ne znaju kako poticati takve oblike rada kojima će aktivirati učenike. Prema istraživanju Perković Krijan i sur. (2017), razina metodičkog znanja učitelja o istraživačkoj je nastavi vrlo dobra, međutim rezultati ispitivanja njihovih znanja upućuju na vrlo nisku razinu metodičkog znanja o istraživačkoj nastavi Prirode i društva. Nadalje, njihovo je istraživanje pokazalo da se samo $32 \%$ varijance provedbe strategija istraživačkog rada može objasniti procjenama metodičkog znanja i procjenama iskustva u istraživačkoj nastavi tijekom školovanja, a da iste prediktorske varijable objašnjavaju 38 \% varijance primjene istraživačkih aktivnosti (Perković Krijan i sur., 2017, str. 136). Autori se pitaju što je s preostalih $65 \%$ neobjašnjene varijance i naglašavaju da postoji očigledan deficit metodičkih znanja učitelja o istraživačkoj nastavi. Prilikom provođenja istraživačkog pristupa važno je da učitelji posjeduju osnovne vještine različitih grana znanosti kako bi mogli provoditi ovaj pristup u suvremenoj nastavi. Stoga se obrazovanje učitelja i profesionalni razvoj još više apostrofira, kao i uloga 
učitelja kao ključnih „agenata promjene“ u implementaciji kurikulnih zahtjeva u procesu stvaranja suvremene škole (Rajić, 2019).

\section{CILJ ISTRAŽIVANJA}

Cilj istraživanja bio je ispitati odgojno-obrazovnu praksu učitelja u realizaciji istraživačkog pristupa u nastavi Prirode i društva, što uključuje njihovo poznavanje istraživačkog pristupa, kompetencije i motivaciju za pripremu i realizaciju istraživačkog pristupa, učestalost provođenja te nastavne oblike rada i nastavne metode koje pritom primjenjuju.

Na temelju definiranog cilja istraživanja postavljena su sljedeća istraživačka pitanja:

1. Jesu li učitelji razredne nastave upoznati s pojmom istraživačkog pristupa u nastavi Prirode i društva?

2. Kako učitelji razredne nastave samovrjednuju vlastite kompetencije za planiranje i provođenje istraživačkog pristupa u nastavi Prirode i društva?

3. Jesu li učitelji razredne nastave motivirani za provođenje istraživačkog pristupa u nastavi Prirode i društva?

4. Koliko često učitelji razredne nastave provode istraživački pristup u nastavi Prirode i društva?

5. Koje nastavne oblike rada i nastavne metode učitelji razredne nastave primjenjuju prilikom provođenja istraživačkog pristupa u nastavi Prirode i društva?

U skladu sa zadatcima, postavljeni su ishodi, odnosno hipoteze glasile:

1. Učitelji razredne nastave upoznati su s pojmom istraživačkog pristupa.

2. Učitelji razredne nastave visoko procjenjuju vlastite kompetencije za planiranje i provođenje istraživačkog pristupa u nastavi Prirode i društva.

3. Učitelji razredne nastave motivirani su za planiranje i provođenje istraživačkog pristupa u nastavi Prirode i društva.

4. Učitelji razredne nastave istraživački pristup u nastavi Prirode i društva ne provode učestalo.

5. Učitelji razredne nastave, prilikom provođenja istraživačkog pristupa u nastavi Prirode i društva, primjenjuju nastavne metode i nastavne oblike rada koji omogućuju aktivno učenje. 


\section{METODOLOGIJA ISTRAŽIVANJA}

U ovom radu postavljeno je pet osnovnih istraživačkih pitanja povezanih $\mathrm{s}$ uključivanjem istraživačkog pristupa u odgojno-obrazovnu praksu učitelja razredne nastave u Primorsko-goranskoj županiji. Problem istraživanja bio je usmjeren na poznavanje istraživačkog pristupa, kompetencije i motivaciju učitelja razredne nastave za planiranje i provođenje istraživačkog pristupa, učestalost provođenja istraživačkog pristupa u nastavi Prirode i društva te nastavne oblike rada i nastavne metode koje učitelji razredne nastave primjenjuju prilikom provođenja istraživačkog pristupa.

\section{UZORAK ISPITANIKA, METODE I POSTUPAK ISTRAŽIVANJA}

U istraživanju su sudjelovala 24 učitelja prvih, drugih, trećih i četvrtih razreda u dvjema osnovnim školama u Primorsko-goranskoj županiji. Istraživanje je provedeno u Osnovnoj školi Ivana Rabljanina u Rabu na otoku Rabu i Osnovnoj školi Nikole Tesle u Rijeci. Podatci su prikupljeni metodom intervjua, odnosno postupkom intervjuiranja. Istraživanje je provedeno tijekom lipnja i srpnja 2020. godine u dvjema osnovnim školama u Primorsko-goranskoj županiji. Za potrebe istraživanja konstruiran je polustrukturirani intervju koji je uključivao jedanaest pitanja: četiri pitanja odnosila su se na upoznatost učitelja razredne nastave s pojmom istraživačkog pristupa te na njihova razmišljanja o pozitivnim i negativnim stranama istraživačkog pristupa; dva pitanja odnosila su se na kompetencije učitelja za planiranje i provođenje istraživačkog pristupa u nastavi Prirode i društva; jednim se pitanjem ispitivalo motivaciju učitelja za provođenje istraživačkog pristupa u nastavi Prirode i društva; učestalost provođenja istraživačkog pristupa u nastavi Prirode i društva i primjeri provedenih istraživački usmjerenih aktivnosti ispitani su dvama pitanjima, kao i korištenje nastavnih oblika rada i nastavne metode koje učitelji razredne nastave primjenjuju prilikom provođenja istraživačkog pristupa u nastavi Prirode i društva. U radu je korišten kvalitativni pristup i metodologija, a podatci dobiveni intervjuiranjem ispitanika analizirani su metodom tematske analize prema Maguire i Delahunt (2017, prema Braun i Clark, 2006) koristeći se kodiranjem u skladu s postavljenim istraživačkim pitanjima (pre-set kodiranje). Prema navedenome, u ovom istraživanju provedena je tematska analiza u šest koraka koji obuhvaćaju: 1. korak: upoznavanje s podatcima (čitanje transkripata i bilježenje); 2. korak: generiranje početnih kodova (kodiranje je provedeno u skladu s istraživačkim pitanjima kao pre-set kodiranje, ali i uz generiranje novih kodova ako ih je moguće identificirati); 3. korak: potraživanje tema (u skladu sa istraživačkim pitanjima, ali i spajanje tema ako se pojave slične tematike unutar kodova); 4. korak: pregled tema (otkrivanje primarnih tema, povezivanje i usklađivanje sa istraživačkim pitanjima); 5. korak: definiranje tema (generiranje primarnih 
i podtema u odnosu na istraživačka pitanja) i 6. korak: zapisivanje (pisanje i opisivanje rezultata istraživanja) (Maguire i Delahunt, 2017, prema Braun i Clark, 2006).

Istraživanje je za potrebe diplomskog rada Istraživački pristup u nastavi prirode $i$ društva provela Karmen Vidas (rujan, 2020) u skladu s odobrenjem Učiteljskoga fakulteta Sveučilišta u Rijeci i uvažavanjem svih etičkih načela $\mathrm{u}$ provedbi istraživanja. Ispitanici su bili upoznati s ciljem istraživanja, koje je bilo dobrovoljno i anonimno. Intervju je bio audio i video sniman, zatim transkribiran, a nakon toga pristupilo se obradi podataka na temelju pre-set kodiranja (istraživačkih pitanja). Uz glavne teme koje su dobivene istraživanjem, prikazane su tipične izjave ispitanika te direktne i indirektne ,veze“ među istraživačkim pitanjima odnosno kodovima. Rezultati su prikazani prema tematskim kategorijama.

\section{REZULTATI I RASPRAVA}

Dobivenim rezultatima izolirane su teme/tematske kategorije koje korespondiraju s postavljenim istraživačkim pitanjima. Rezultatima ovog istraživanja dobiveno je pet tematskih kategorija, koje su odgovarale postavljenim istraživačkim pitanjima te koji su koristili kao kodovi u provođenju tematske analize. Prikazujemo ih na Slici 1.

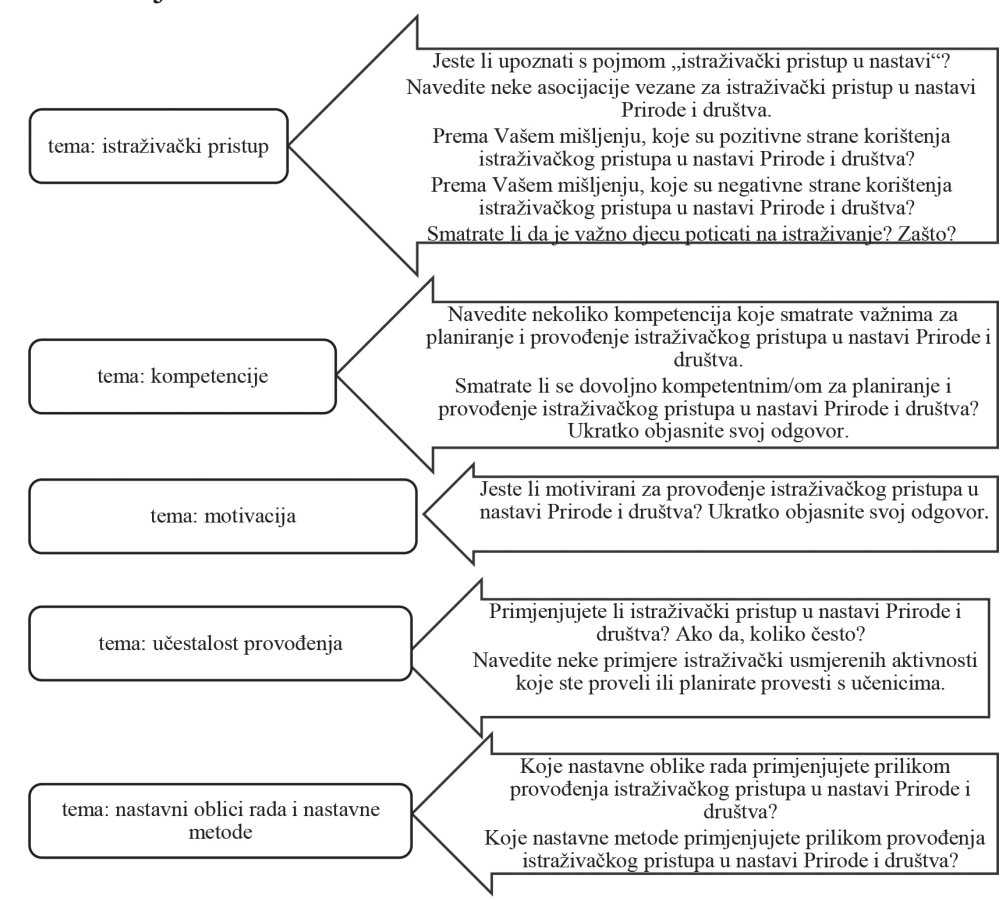

Slika 1. Tematska mapa analize: tematske kategorije i istraživačka pitanja 


\section{REZULTATI ISTRAŽIVANJA O UPOZNATOSTI UČITELJA RAZREDNE NASTAVE S POJMOM ISTRAŽIVAČKOG PRISTUPA U NASTAVI PRIRODE I DRUŠTVA}

Prva tematska kategorija odnosila se na istraživački pristup, a sadržavala je četiri pitanja. Na prvo pitanje u tematskoj kategoriji istraživački pristup ispitanici su u intervjuu trebali odgovoriti jesu li upoznati s pojmom istraživačkog pristupa u nastavi Prirode i društva te nakon toga navesti asocijacije (kao implicitnu tehniku) vezane za istraživački pristup u nastavi Prirode i društva. Svi ispitanici odgovorili su da su upoznati s pojmom istraživačkog pristupa, a asocijacije vezane za istraživački pristup koje su navodili bile su: istraživanje/ samostalno istraživanje; spoznaja/spoznavanje/samostalno dolaženje do spoznaja; samostalnost/samostalno otkrivanje i rješavanje problema; aktivno učenje/aktivan učenik/veća angažiranost učenika; kreativnost učenika/poticanje kreativnosti; promatranje/promatranje prirode/promatranje po godišnjim dobima; neposredno promatranje/neposredna stvarnost; zainteresiranost; uzbuđenje; zanimljiva nastava; ideje; uspoređivanje; demonstracije; eksperimenti; pokusi; problemski zadatci; kritičko mišljenje; zaključivanje; timski rad; snalaženje; iskustva/iskustveno učenje; izvanučionička nastava i samovrjednovanje.

Rezultati istraživanja o upoznatosti učitelja razredne nastave s pojmom istraživačkog pristupa u nastavi Prirode i društva temeljeni na odgovorima ispitanika uputili su na to da dobivene asocijacije vezane za istraživački pristup u nastavi Prirode i društva odgovaraju definiciji istraživačkog pristupa koju donosi Kurikulum nastavnog predmeta Priroda i društvo za osnovne škole. Prilikom usporedbe definicije istraživačkog pristupa, koja glasi: „Istraživačkim pristupom učenik razvija vještine koje će kasnije primijeniti i u svakodnevnome životu te na temelju kritičkoga razmatranja valjanih dokaza i argumenata donositi relevantne odluke. Istraživački pristup pridonosi razvijanju znatiželje, kreativnosti, vještina promatranja, uspoređivanja, razvrstavanja, postavljanja pitanja, predviđanja, analiziranja, generaliziranja, vrednovanja, komuniciranja, prikupljanja informacija i slično" (Kurikulum nastavnog predmeta Priroda $i$ društvo za osnovne škole, 2019, str. 8), i dobivenih rezultata istraživanja zaključuje se da su učitelji razredne nastave upoznati s pojmom istraživačkog pristupa te ga asocijacijacijama točno opisuju. Nadalje, u drugom pitanju u tematskoj kategoriji istraživački pristup, ispitanici su trebali navesti pozitivne strane istraživačkog pristupa u nastavi Prirode i društva. Rezultati istraživanja temeljeni na odgovorima ispitanika upućuju na to da se učitelji razredne nastave slažu da postoji puno pozitivnih strana istraživačkog pristupa, što je u skladu s dosadašnjim istraživanjima (Letina, 2016, 2020). Ispitanici su navodili različite pozitivne strane korištenja istraživačkog pristupa u nastavi Prirode i društva poput stjecanja trajnijih znanja, lakšeg usvajanja nastavnog sadržaja, veće motiviranosti učenika, razvijanja sposobnosti i vještina važnih za svakodnevni 
život učenika, razvijanja pozitivnog stava prema učenju, razvijanja samostalnosti i kreativnosti učenika, razvijanja kritičkog mišljenja, socijalizacije učenika i stjecanja iskustava. Neki od primjera stavova ispitanika iskazani su izjavama navedenima u nastavku:

Pojmovi koji se usvajaju istraživanjem učenicima duže ostaju u sjećanju te ih općenito bolje pamte, a takav način rada ih većinom veseli.

Pozitivna strana istraživačkog pristupa je u tome što učenici istraživanjem mogu puno lakše usvojiti nastavno gradivo i to na način da prirodu ne upoznaju samo kroz suhoparno gradivo, već kroz samo iskustvo koje stječu tijekom istraživačkog načina rada.

Uvođenjem istraživačkog pristupa u nastavu prirode i društva, učenik razvija sposobnosti $i$ vještine na temelju svog iskustva $i$ istraživanja te samim time pridonosi osobnom razvoju i usvajanju znanja.

Prilikom provođenja istraživačkog pristupa, do izražaja dolazi kreativnost i samostalnost učenika. Učenik pritom samostalno uočava i dolazi do spoznaja o promjenama u okolini te donosi zaključke. Uz to je naglašena socijalizacija učenika zbog korištenja rada u skupinama.

U trećem pitanju u tematskoj kategoriji istraživački pristup ispitanici su trebali navesti negativne strane istraživačkog pristupa u nastavi Prirode i društva. Rezultati istraživanja temeljeni na odgovorima ispitanika upućuju na to da se učitelji razredne nastave slažu u mišljenjima da postoji manje negativnih strana istraživačkog pristupa. Kao negativne strane ispitanici su najčešće navodili nedostatak vremena te tehničku neopremljenost škola, što uključuje nedostatak materijala i pribora za istraživanje. U manjoj mjeri navodili su problem težeg održavanja discipline prilikom provođenja istraživačkog pristupa u nastavi Prirode i društva. Izdvajamo ključne izjave:

Jedino što je moguće je da nema sredstava i materijala za istraživački rad, iako se svatko snalazi s onime što ima.

Takav pristup u nastavi obično iziskuje više vremena pa se ponekad ne može provoditi u mjeri u kojoj bismo ga inače provodili.

Negativne strane kod provođenja istraživačkog pristupa su nedostupnost pojedinih sredstava i pomagala za rad te teže održavanje discipline.

Posljednje pitanje u tematskoj kategoriji istraživački pristup bilo je usmjereno na iznošenje mišljenja ispitanika o važnosti poticanja djece na istraživanje. Rezultati istraživanja temeljeni na odgovorima ispitanika pokazali su da se svi ispitanici slažu da je djecu važno poticati na istraživanje. U većini slučajeva ispitanici su navodili da je poticanje djece na istraživanje važno zbog poticanja kritičkog razmišljanja i logičkog zaključivanja, razvijanja vještina i sposobnosti potrebnih za svakodnevni život te stjecanja trajnijih znanja i time temelja za cjeloživotno učenje (Letina, 2020). Neki od primjera stavova ispitanika iskazani su izjavama navedenim u nastavku: 
Itekako je važno poticati djecu na istraživanje. Istraživanjem razvijaju sva osjetila, kritički razmišljaju te na temelju opažanog zaključuju. Istraživanje je jako zanimljivo učenicima i takav oblik nastave ih motivira za daljnji rad.

Svakako je važno poticati djecu na istraživanje. Djeca na taj način razvijaju maštu, brže povezuju i zaključuju, a ponekad i sami dolaze do novih ideja istraživanja. Također smatram da se ponekad osjećaju i korisnijim zato što aktivnije sudjeluju u nastavi i postaju samostalniji.

Važno je poticati djecu na istraživanje jer ih se time osposobljava za samostalan rad. Djeca istražuju, otkrivaju i usvajaju trajna znanja... Istraživanjem, a posebice eksperimentom, ostvaruje se povezanost teorije s praksom.

$\mathrm{Na}$ temelju dobivenih rezultata istraživanja moguće je zaključiti, u odnosu na dobivenu tematsku kategoriju istraživački pristup, da su učitelji razredne nastave dobro upoznati s pojmom istraživačkog pristupa. Prilikom navođenja pozitivnih i negativnih strana istraživačkog pristupa ispitanici su navodili pozitivne i negativne strane istraživačkog pristupa koje su u skladu s dosadašnjim spoznajama o istraživačkom pristupu kao jednoj od ključnih značajki suvremene nastave. Time su ispitanici dodatno pokazali poznavanje pojma istraživačkog pristupa. Rezultati istraživanja upućuju i na to da se učitelji slažu s činjenicom da istraživački pristup u nastavi Prirode i društva ima više pozitivnih nego negativnih strana. Također, rezultati upućuju na to da se učitelji slažu u da je učenike važno poticati na istraživanje zbog pozitivnih učinaka tih oblika rada na daljnje učenje i poučavanje, posebice obrazovnih, ali i odgojnih učinaka. Rezultati istraživanja upućuju i na to da ispitanici opisuju značajke suvremene nastave, odnosno istraživačkog pristupa kao oblika suvremene nastave kojom se aktivira učenikova uloga u nastavnom procesu, potiču oblici suradničkog učenja, a kreativnost učenika usmjerena je na razvoj prirodoznanstvene pismenosti (Letina, 2016, 2020; Pećar i sur., 2020). Međutim, jasno je da, iako s jedne strane učitelji očigledno prepoznaju važnost istraživačkog pristupa kao suvremenog oblika nastave, nemogućnost njegove realizacije povezuju s nedostatkom materijalnih sredstava i vremena, što s druge strane upućuje na nedostatnu upoznatost s brojnim mogućnostima realizacije pristupa kojima se takve poteškoće mogu kvalitetno premostiti i riješiti poput upotrebe različitih digitalnih alata (Anđić i sur., 2020).

\section{REZULTATI ISTRAŽIVANJA O KOMPETENCIJAMA UČITELJA RAZREDNE NASTAVE ZA PLANIRANJE I PROVOĐENJE ISTRAŽIVAČKOG PRISTUPA U NASTAVI PRIRODE I DRUŠTVA}

Druga tematska kategorija pod nazivom kompetencije sadržavala je dva pitanja. Prvo pitanje u tematskoj kategoriji kompetencije odnosilo se na navođenje kompetencija učitelja razredne nastave koje ispitanici smatraju važnim 
za planiranje i provođenje istraživačkog pristupa u nastavi Prirode i društva. Rezultati istraživanja temeljeni na odgovorima ispitanika upućuju na to da učitelji razredne nastave važnim za planiranje i provođenje istraživačkog pristupa u nastavi Prirode i društva smatraju sljedeće kompetencije: poznavanje struke, posjedovanje znanja, sposobnost planiranja i pripremanja istraživački usmjerenog nastavnog sata, stvaranje poticajnog okruženja, sposobnost komuniciranja i vođenja, sposobnost praćenja i provjeravanja te digitalnu kompetenciju. Osim toga, ispitanici su obično navodili poželjne osobine učitelja kao što su strpljivost, istraživački duh, otvorenost novim idejama, snalažljivost, upornost, organiziranost i slično. Sve navedeno ne spada pod problem istraživanja ovoga rada, ali svakako nije na odmet prilikom provođenja istraživačkog pristupa u nastavi Prirode i društva. U drugom pitanju u tematskoj kategoriji kompetencije ispitanici su trebali odgovoriti smatraju li se kompetentnima za planiranje i provođenje istraživačkog pristupa u nastavi Prirode i društva. Ispitanici su ponudili odgovore na temelju kojih se mogu izvesti sljedeći rezultati. Većina ispitanika smatra se kompetentnima za planiranje i provođenje istraživačkog pristupa u nastavi Prirode i društva. U većini slučajeva ispitanici su odgovorili da se smatraju kompetentnima za planiranje i provođenje istraživačkog pristupa u nastavi Prirode i društva zbog godina iskustva i rada u razrednoj nastavi kao i zbog pohađanja programa stručnog usavršavanja. Manji broj ispitanika smatra se djelomično kompetentnim za planiranje i provođenje istraživačkog pristupa u nastavi Prirode i društva. Najmanji broj ispitanika ne osjeća se kompetentnim za planiranje i provođenje istraživačkog pristupa u nastavu Prirode i društva. Ispitanici koji se osjećaju nedovoljno kompetentnima ili se uopće ne osjećaju kompetentnima smatraju da je potrebno mnogo iskustva i znanja kako bi se stekao osjećaj kompetentnosti za planiranje i provođenje istraživačkog pristupa u nastavi, a naglasili su i važnost dodatnog educiranja. Neki od primjera stavova ispitanika iskazani su izjavama navedenim u nastavku:

Smatram se kompetentnom s obzirom na godine iskustva i permanentno usavršavanje.

Smatram se kompetentnom, a i osobno volim puno praktičnog rada u nastavi što nastojim prenositi i na učenike.

Smatram da sam kompetentna za planiranje i provođenje istraživačkog pristupa u nastavi prirode i društva zbog iskustva rada s učenicima.

Smatram se dovoljno kompetentnom, ali nažalost, sav naš nastavni plan $i$ program nerijetko tjera na brz tempo obrade novih nastavnih sadržaja pa se često dogodi da za takav oblik nastave nema dovoljno mjesta.

Smatram se dovoljno kompetentnom za planiranje i provođenje istraživačkog pristupa u nastavi prirode i društva jer ga već dugo u svome radu primjenjujem i moji učenici uživaju u njemu. Njihovi su rezultati najbolji dokaz o kompetencijama. 
Ne smatram se dovoljno kompetentnom. Mislim da mi je potrebno još mnogo iskustva i znanja.

Prema navedenim rezultatima istraživanja moguće je zaključiti da se učitelji razredne nastave u velikoj mjeri osjećaju kompetentnima za planiranje i provođenje istraživačkog pristupa u nastavi Prirode i društva, a to pripisuju vlastitom iskustvu u radu s djecom te stručnim usavršavanjima. S druge strane, manji broj učitelja smatra se nedovoljno kompetentnim za planiranje i provođenje istraživačkog pristupa u nastavi Prirode i društva te smatraju da im je potrebno više iskustva u radu i dodatna educiranja kako bi stekli potrebne kompetencije za provođenje istraživačkog pristupa u nastavi Prirode i društva. Međutim, ovi se rezultati mogu pripisati godinama radnog iskustva učitelja, što znači da učitelji koji imaju manje godina radnog iskustva u razrednoj nastavi mogu imati osjećaj posjedovanja manjeg broja kompetencija. Takvi rezultati slažu se s rezultatima istraživanja Pavin i sur. (2003). Rezultati tog istraživanja pokazali su da je studij učiteljima najviše omogućio stjecanje znanja iz nastavnih predmeta, primjene nastavnih metoda, planiranje nastavnih sati te određivanje nastavnih ciljeva, a stjecanje ostalih kompetencija potrebnih za provođenje složenijih oblika rada nije im bilo omogućeno (Pavin i sur., 2005). Prema tome, mlađi učitelji mogu se osjećati manje kompetentnima. Zbog toga što organizacija i provedba složenijih oblika rada poput istraživačkog pristupa učiteljima često predstavlja problem, važno je omogućiti učiteljima sustav podrške. Prema rezultatima istraživanja, uviđa se da su dodatna educiranja učiteljima pomogla u stjecanju novih kompetencija. Letina (2012) zbog toga naglašava potrebu pružanja programa usavršavanja učiteljima razredne nastave koji će učiteljima omogućiti stjecanje novih i razvijanje postojećih kompetencija. Kako autorica ističe, takoučitelji mogu zadovoljiti zahtjeve novih suvremenih kurikulnih zahtjeva (Letina, 2012; Letina, 2019).

\section{REZULTATI ISTRAŽIVANJA O MOTIVACIJI UČITELJA ZA PROVOĐENJE ISTRAŽIVAČKOG PRISTUPA U NASTAVI PRIRODE I DRUŠTVA}

Treća tematska kategorija pod nazivom motivacija sadržavala je jedno pitanje. Pitanje se odnosilo na motivaciju učitelja za planiranje i provođenje istraživačkog pristupa u nastavi Prirode i društva. Dobiveni rezultati istraživanja upućuju na to da su ispitanici motivirani za planiranje i provođenje istraživačkog pristupa u nastavi Prirode i društva. Svi ispitanici odgovorili su da su motivirani za planiranje i provođenje istraživačkog pristupa u nastavi Prirode i društva, a kao razlog tomu navodili su veću motiviranost učenika prilikom korištenja istraživačkog pristupa, stjecanje trajnijih znanja, poticanje kritičkog načina razmišljanja i logičkog zaključivanja kod učenika, kreativniji pristup učenju, zanimljivost nastave, bolje ishode učenja i činjenicu da učenici vole 
istraživačke aktivnosti. Neki od primjera stavova ispitanika iskazani su izjavama navedenim u nastavku:

Motivirana sam za provođenje istraživačkog pristupa u nastavi Prirode $i$ društva. Uspješni i zadovoljni učenici te ostvarenost ishoda su mi velika motivacija u provođenju tog pristupa.

Motivirana sam jer primjećujem da učenici vole takav oblik nastave.

Motivirana sam jer smatram da je takav oblik nastave puno kreativniji i zanimljiviji učenicima, a najbitnije mi je da putem istraživačkog pristupa učenici ostvaruju bolje ishode učenja te i sami postaju više motivirani.

Prema rezultatima istraživanja, može se zaključiti da učitelji razredne nastave povezuju svoju motiviranost za provođenje istraživačkog pristupa u nastavi Prirode i društva s pozitivnim stranama istraživačkog pristupa. Osim toga, učitelji su navodili da bez obzira na svoju motivaciju, često ne mogu provoditi istraživački pristup u nastavi Prirode i društva zbog određenih ograničavajućih čimbenika poput manjka vremena i sredstava.

Ovakve rezultate možemo povezati s rezultatima istraživanja Borić i sur. (2010). Naime, Borić i sur. (2010) u zaključku svojeg istraživanja dokazuju da je povezanost percipiranih prednosti istraživačke nastave i motivacije učitelja statistički značajna. Osim toga, dolaze do zaključka da kompetentniji i motiviraniji učitelji češće navode više prednosti istraživački usmjerene nastave. Nadalje, Perković Krijan (2016) u svojem se doktorskom radu dotiče problema zadovoljstva poslom te dolazi do zaključka da učitelji s više iskazanog metodičkog znanja i više zadovoljstva češće primjenjuju istraživačke aktivnosti od učitelja s manje iskazanog metodičkog znanja i manje zadovoljstva. Prema tome, može se zaključiti da su učitelji koji pokazuju više zadovoljstva poslom ujedno i motiviraniji te zbog toga češće provode istraživački pristup u nastavi Prirode i društva.

\section{REZULTATI ISTRAŽIVANJA O UČESTALOSTI PROVOĐENJA ISTRAŽIVAČKOG PRISTUPA U NASTAVI PRIRODE I DRUŠTVA}

Četvrta tematska kategorija nosila je naziv učestalost provođenja te je sadržavala dva pitanja. U prvom pitanju u tematskoj kategoriji učestalost provođenja ispitanici su trebali odgovoriti koliko često u nastavi Prirode i društva provode istraživački pristup. Rezultati istraživanja upućuju na postojanje različite prakse učitelja razredne nastave, a odgovori ispitanika u velikoj su se mjeri razlikovali. Ispitanici su ponudili odgovore na temelju kojih mogu se izvesti sljedeći rezultati. Najviše ispitanika istraživački pristup u nastavi Prirode i društva provodi nekoliko puta godišnje. Manji broj ispitanika istraživački pristup u nastavi Prirode i društva provodi nekoliko puta mjesečno. Samo jedan ispitanik istraživački pristup u nastavi Prirode i društva provodi u svakoj 
nastavnoj temi. Neki od primjera odgovora ispitanika iskazani su izjavama navedenima u nastavku:

U prvom i drugom razredu koristim ga rijetko, a u trećem i četvrtom nekoliko puta godišnje.

U prvom i drugom razredu rjeđe koristim istraživački pristup, ali u trećem i četvrtom razredu nekoliko puta mjesečno.

Istraživački pristup u nastavi Prirode i društva koristim često unutar učionice, i to nekoliko puta mjesečno, ali što se tiče izvanučionične nastave rjeđe nego prije zbog silnih suglasnosti koje roditelji moraju potpisivati pa se nastava svodi na zadovoljavanje papirologije.

Istraživački pristup u nastavi Prirode i društva koristim u svakoj nastavnoj temi jer vidim veliku važnost u praktičnom radu učenika.

U drugom pitanju u tematskoj kategoriji učestalost provođenja ispitanici su trebali navesti neke primjere istraživački usmjerenih aktivnosti koje su proveli ili planiraju provesti s učenicima. Rezultati istraživanja upućuju na to da učitelji razredne nastave najčešće provode sljedeće aktivnosti: pokusi s vodom, sadnja i promatranje rasta biljke, herbarij, pokusi vezani za uvjete života, istraživanje mjesta stanovanja, određivanje strana svijeta, praćenje vremenskih prilika u zavičaju, upoznavanje kulturne baštine, jela naših predaka, vođenje evidencije o aktivnostima iz svakodnevnog života učenika, svojstva vode, agregatna stanja vode, izrada kompasa i mjerenje temperature zraka. Neki od primjera odgovora ispitanika iskazani su izjavama navedenima u nastavku:

Učenici su promatrali zagrijavanje i isparavanje vode.

Učenici su posijali sjeme i pratili napredak biljke. Jedna je biljka bila na svjetlosti, druga u tami. Jednu su zalijevali, a drugu nisu i slično.

Učenici su istraživali o jelima naših predaka i načinu na koji su se pripremala.

Prilikom učenja o zdravoj prehrani s učenicima sam provela aktivnost Moj najbolji smoothie.

Ubuduće planiram s učenicima provesti neki oblik istraživanja u kojem će oni sami izabrati što će istraživati te o istom napraviti kratko prezentiranje... Međutim, to planiram provesti kada učenici budu samostalniji i kada usvoje vještine kojima sami mogu doći do kreativnih rješenja i samostalnog prezentiranja.

$\mathrm{Na}$ temelju rezultata istraživanja, zaključuje se da većina ispitanika istraživački pristup u nastavi Prirode i društva još uvijek provodi u vrlo maloj mjeri, samo nekoliko puta u nastavnoj godini. Ispitanici provođenje istraživačkog pristupa u nastavi Prirode i društva u velikoj mjeri povezuju s nedostatcima istraživačkog pristupa. Prema rezultatima istraživanja, u većini slučajeva kao razlog ne tako čestog provođenja istraživačkog pristupa u nastavi Prirode i društva navode nedostatak vremena te nedostatak sredstava potrebnih za istraživanje. Također, rezultati istraživanja upućuju i na to da učitelji istraživački pristup 
češće koriste u trećem i četvrtom razredu, a rjeđe u prvom i drugom razredu. Ovakvi rezultati djelomično se podudaraju s rezultatima istraživanja koje su provele Borić i sur. (2010). Rezultati tog istraživanja pokazuju da se najveći postotak učitelja, i to čak njih $42 \%$, izjašnjava da istraživački oblik nastave provodi samo jednom mjesečno, a samo $10 \%$ učitelja to čini jednom tjedno. Rezultati istraživanja Borić i sur. (2010) upućuju na činjenicu da nedovoljan broj učitelja realizira ovakav oblik nastave bez obzira na sve njezine prednosti. Osim toga, autorice također dolaze do zaključka da se istraživačka nastava češće provodi u trećim i četvrtim razredima, a manje u prvim i drugim razredima. U ovom slučaju, rezultati istraživanja poklapaju se iako nije točno poznat razlog zbog čega se istraživački pristup češće provodi u trećem i četvrtom razredu, ali možemo pretpostaviti da je razlog tome lakša organizacija i provođenje istraživačkih aktivnosti sa starijim učenicima. U ovom slučaju ostavljen je prostor za neka buduća istraživanja koja bi mogla uputiti na razloge dobivanja takvih rezultata. Na temelju rezultata istraživanja zaključuje se i da učitelji, iako ga provode rijetko, prilikom provođenja istraživačkog pristupa koriste istraživačke aktivnosti koje omogućuju zauzimanje aktivnije uloge učenika.

\section{REZULTATI ISTRAŽIVANJA O ODABIRU NASTAVNIH OBLIKA RADA I NASTAVNIH METODA PRILIKOM PROVOĐENJA ISTRAŽIVAČKOG PRISTUPA U NASTAVI PRIRODE I DRUŠTVA}

Posljednja tematska kategorija odnosila se na nastavne oblike rada i nastavne metode, a uključivala je dva pitanja. U prvom pitanju tematske kategorije nastavni oblici rada i nastavne metode ispitanici su trebali navesti nastavne oblike rada koje primjenjuju prilikom provođenja istraživačkog pristupa u nastavi Prirode i društva. Na temelju odgovora ispitanika dobiveni su sljedeći rezultati. Ispitanici prilikom provođenja istraživačkih aktivnosti najčešće primjenjuju rad u paru i rad u skupinama. Manji broj ispitanika prilikom provođenja istraživačkog pristupa u nastavi Prirode i društva primjenjuje individualni rad. Najmanji broj ispitanika prilikom provođenja istraživačkog pristupa primjenjuje frontalni rad u kombinaciji s radom u paru i radom u skupinama. U drugom pitanju tematske kategorije nastavni oblici rada i nastavne metode ispitanici su trebali navesti nastavne metode koje primjenjuju prilikom provođenja istraživačkog pristupa u nastavi Prirode i društva. Rezultati istraživanja temeljeni na odgovorima ispitanika upućuju na to da učitelji razredne nastave prilikom provođenja istraživačkog pristupa u nastavi Prirode i društva najčešće primjenjuju metodu praktičnog rada, metodu eksperimentiranja, metodu razgovora, metodu usmenog izlaganja i metodu promatranja. Prema navedenim rezultatima istraživanja temeljenim na odgovorima ispitanika o nastavnim oblicima rada i nastavnim metodama, zaključuje se da ispitanici prilikom provođenja 
istraživačkog pristupa u nastavi Prirode i društva primjenjuju aktivne metode rada koje učenicima omogućuju aktivno sudjelovanje u nastavi. Također, rezultati istraživanja pokazuju da učitelji prilikom provođenja istraživačkog pristupa u nastavi najčešće primjenjuju poželjne oblike rada poput rada u paru i rada u skupinama u kojima učenici mogu aktivno učiti, surađivati i razvijati vještine (Alagić, 2021; Letina, 2015, 2019).

$\mathrm{Na}$ temelju dobivenih rezultata istraživanja moguće je ocrtati tematsku mapu smjera kodova dobivenih unutar tematskih kategorija o istraživačkom pristupu kao suvremenom obliku nastave (Slika 2.).

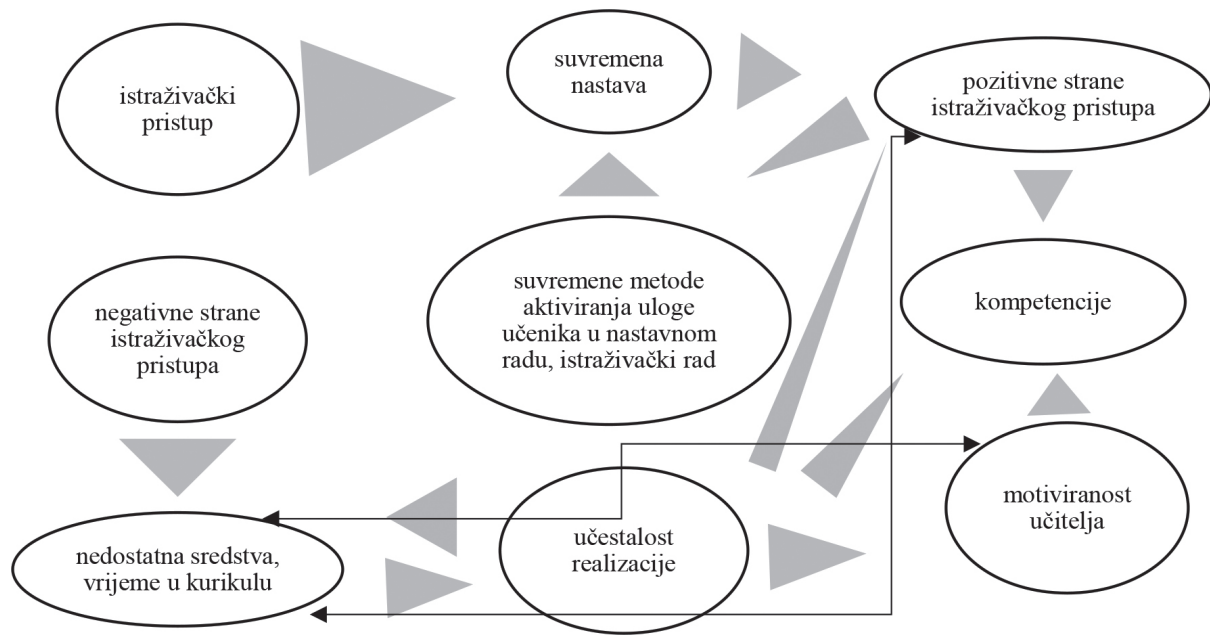

Slika. 2. Tematska mapa analize: rezultati istraživanja mišljenja učitelja o istraživačkom pristupu (direktne i indirektne veze)

Kako je prikazano Slikom 2., među rezultatima je moguće uočiti direktne $\mathrm{i}$ indirektne veze međupovezanosti kodiranih odgovora ispitanika, odnosno istraživačkih pitanja i tematskih kategorija. Međuzavisnost realizacije istraživačkog pristupa odgovara značajkama suvremene nastave koja korespondira $\mathrm{s}$ aktivnom ulogom učenika. Pozitivne strane istraživačkog pristupa povezane su s motivacijom učitelja, kompetencijama i učestalosti realizacije. Na isti način negativni učinci povezani su s deficitima koje ispitanici ističu (sredstava, vrijeme u kurikulu) i učestalošću koju procjenjujemo još uvijek nedostatnom. Indirektni kod dobiven je na povezanosti negativnih strana, odnosno deficita mogućnosti realizacije i pozitivnih učinaka istraživačkog pristupa i motiviranosti učitelja, pri čemu se neizostavno apostrofira značaj uloge i kompetencija učitelja. Tako su dobiveni rezultati u skladu s dosadašnjim istraživanjima prakse rada učitelja o istraživačkoj nastavi (Anđić i sur., 2020; Letina, 2015, 2019, 2020; Pavin i sur., 2005). 


\section{ZAKLJUČCI ISTRAŽIVANJA}

Rezultati kvalitativnog istraživanja koje je provedeno s učiteljima $(\mathrm{N}=24)$ prvih, drugih, trećih i četvrtih razreda u osnovnim školama Primorsko-goranske županije upućuju na to da istraživački pristup još uvijek nije dostatno implementiran, što je u određenoj mjeri i očekivano.

Kvalitativnim istraživanjem, koje je prikazano ovim radom, utvrdila su se mišljenja učitelja o istraživačkom pristupu u nastavi Prirode i društva. U provođenju istraživačkog pristupa važnu ulogu nose upravo učitelji i njihova mišljenja o istraživačkom pristupu koji je jedna od ključnih značajka suvremene nastave u hrvatskim školama. Istraživanje je bilo provedeno postupkom intervjuiranja i rezultati su analizirani metodom tematske analize, odnosno kodiranjem u skladu s istraživačkim pitanjima. Identificirano je pet ključnih tematskih kategorija. Prva tematska kategorija bila je istraživački pristup, a odnosila se na upoznatost učitelja razredne nastave s pojmom istraživačkog pristupa u nastavi Prirode i društva. Rezultati istraživanja uputili su na to da su učitelji razredne nastave upoznati s pojmom istraživačkog pristupa te se slažu u mišljenju da istraživački pristup u nastavi Prirode i društva donosi puno više pozitivnih nego negativnih strana. Osim toga, rezultati istraživanja temeljeni na odgovorima ispitanika pokazali su da se svi ispitanici slažu da je djecu važno poticati na istraživanje, a kao razloge navodili su poticanje kritičkog razmišljanja i logičkog zaključivanja, razvijanje vještina i sposobnosti potrebnih za svakodnevni život te stjecanje trajnijih znanja. Time je ostvarena pretpostavka ovog istraživanja prema kojoj se očekivalo da će učitelji biti upoznati s pojmom istraživačkog pristupa. Druga tematska kategorija nazvana je kompetencije, a odnosila se na kompetencije učitelja za planiranje i provođenje istraživačkog pristupa u nastavi Prirode i društva. Provjeravale su se samovrjednovane kompetencije učitelja razredne nastave. Rezultati istraživanja uputili su na to da se većina ispitanika smatra kompetentnima za planiranje i provođenje istraživačkog pristupa u nastavi Prirode i društva, a kao razlog tomu navode godine iskustva i rada u razrednoj nastavi, kao i pohađanje programa stručnog usavršavanja. Manji broj ispitanika odgovorio je da se smatra djelomično kompetentnim za planiranje i provođenje istraživačkog pristupa u nastavi Prirode i društva, a najmanji broj ispitanika odgovorio je da se smatra nekompetentnima za planiranje i provođenje istraživačkog pristupa u nastavu Prirode i društva. Kao razlog tomu navodili su potrebu stjecanja dodatnog iskustva i znanja te potrebu dodatnog educiranja. Ostvaren je ishod ovog istraživanja prema kojem se očekivalo da će učitelji razredne nastave visoko procijeniti vlastite kompetencije za planiranje i provođenje istraživačkog pristupa u nastavi Prirode i društva. Treća tematska kategorija nazvana je motivacija, a odnosila se na motivaciju učitelja razredne nastave za provođenje istraživačkog pristupa u nastavi Prirode i društva. Provjeravalo se jesu li učitelji razredne nastave motivirani za planiranje i 
provođenje istraživačkog pristupa u nastavi Prirode i društva. Rezultati istraživanja uputili su na to da su učitelji razredne nastave motivirani za planiranje i provođenje istraživačkog pristupa u nastavi Prirode i društva te da svoju motiviranost povezuju s pozitivnim posljedicama istraživačkog pristupa, poput veće motiviranosti učenika prilikom korištenja istraživačkog pristupa, stjecanja trajnijih znanja, poticanja kritičkog načina razmišljanja i logičkog zaključivanja kod učenika, zanimljivosti nastave, boljih ishoda učenja i činjenice da učenici vole istraživačke aktivnosti. Osim toga, učitelji su navodili da, bez obzira na svoju motivaciju i pozitivne strane istraživačkog pristupa, često nemaju mogućnost provođenja istraživačkog pristupa u nastavi Prirode i društva zbog određenih ograničavajućih čimbenika poput manjka vremena i sredstava. Ostvaren je ishod, odnosno potvrđena hipoteza ovog istraživanja o motiviranosti učitelji razredne nastave za provođenje istraživačkog pristupa u nastavi Prirode i društva zbog prednosti koje donosi. Četvrta tematska kategorija bila je učestalost provođenja. Rezultati istraživanja pokazali su da učitelji razredne nastave istraživački pristup u nastavi Prirode i društva obično provode nekoliko puta godišnje, što je premalo za ostvarivanje ciljeva suvremene nastave Prirode i društva. Time je potvrđena hipoteza ovog istraživanja prema kojoj se očekivalo da će učitelji u manjoj mjeri odgovoriti da ovakav oblik nastave s obzirom na učestalost provode. Peta tematska kategorija bila je nastavni oblici rada $i$ nastavne metode, a odnosila se na nastavne oblike rada i nastavne metode koje učitelji primjenjuju u provođenju istraživačkog pristupa u nastavi Prirode i društva. Rezultati istraživanja uputili su na to da učitelji razredne nastave prilikom provođenja istraživačkog pristupa u nastavi Prirode i društva primjenjuju aktivne metode rada koje učenicima omogućuju aktivno sudjelovanje $u$ nastavi. Također, rezultati istraživanja upućuju na to da učitelji prilikom provođenja istraživačkog pristupa u nastavi najčešće primjenjuju poželjne oblike rada poput rada u paru i rada u skupinama u kojima učenici mogu aktivno učiti, surađivati i razvijati vještine. Ostvaren je i posljednji ishod, odnosno potvrđena hipoteza ovog istraživanja prema kojoj se očekivalo da će učitelji odgovoriti da prilikom provođenja istraživačkog pristupa u nastavi Prirode i društva primjenjuju nastavne metode i nastavne oblike rada koji omogućuju aktivno učenje.

U skladu s tim jesu i ograničenja ovog istraživanja, koja se odnose na nereprezentativnost uzorka i njegovu specifičnost, stoga prema tome i nemogućnost generalnog zaključivanja na temelju dobivenih rezultata. Međutim, važno je naglasiti da zaključke koje interpretiramo treba prihvatiti s oprezom i kao tek indikativne pokazatelje. Dobiveni rezultati istraživanja u velikoj su mjeri pozitivni i potvrđuju dosadašnje rezultate pojedinih istraživanja. Učitelji razredne nastave upoznati su s pojmom istraživačkog pristupa te su motivirani za provođenje istraživačkog pristupa u nastavi Prirode i društva. Osim toga, učitelji razredne nastave u velikoj mjeri smatraju da posjeduju određene kompetencije potrebne za planiranje i provođenje istraživačkog pristupa u nastavi Prirode i 
društva te primjenjuju nastavne metode i nastavne oblike rada koji omogućuju veću aktivnost učenika. Međutim, istraživački se pristup u nastavi Prirode i društva ne provodi u dovoljnoj mjeri. Kada se dobivene rezultate sagleda u cjelini, zaključuje se da učiteljima razredne nastave češće uključivanje istraživačkog pristupa u nastavu Prirode i društva onemogućava nedostatak vremena te nastavnih sredstava i pomagala potrebnih za istraživanje. To upućuje na to da još uvijek postoje zaprjeke u njegovoj većoj implementaciji koje se temelje na nedostatnim kompetencijama učitelja, ali i neprepoznavanju brojnih i različitih mogućnosti koje nude suvremene multimedijalne metode, pomagala i sredstva $\mathrm{u}$ realizaciji istraživačkog pristupa u osnovnim školama.

U konačnici, u tom kontekstu i dalje ostaje nedogovoreno pitanje o samom istraživačkom pristupu: Je li on tek odmak od tradicionalnosti ili zaista govorimo o suvremenoj nastavi? Na to pitanje još je uvijek teško odgovoriti iz nekoliko razloga. Istraživački je pristup s jedne strane novi pristup u nastavi Prirode i društva, a s druge strane moguće je zaključiti da je s obzirom na metodiku rada u nastavi Prirode i društva on oduvijek bio njezin sastavni dio. Istraživački pristup ili njegovi oblici rada postojali su i ranije i bili dio koncepcija alternativnih pedagogijskih i didaktičkih pravaca. De Zan (2010), Matijević (2005), Letina (2015) i drugi autori istraživački pristup stavljaju u kontekst nastave Prirode i društva, a istraživački rad učenika jest dio učenja i poučavanja Prirode i društva. Istodobno, istraživački pristup koji je toliko naglašen u novom kurikulu nastavnog predmeta Priroda i društvo, kao metodološki pristup, pridodaje njemu pripadnim oblicima i metodama rada novo značenje, stoga se može smatrati značajkom suvremene nastave jer, između ostaloga, unaprjeđuje kompetencije učenika i samoregulira učenje (Letina, 2020). Međutim, je li to dovoljno da bi nastavu nazivali suvremenom? Mi procjenjujemo da je to svakako dobar početak, međutim Kurikulum je još uvijek „nov“, a implementacija istraživačkog pristupa kao suvremenog oblika nastave uvelike ovisi o učiteljima, njihovim kompetencijama, ali i drugim čimbenicima, što je prikazano ovim istraživanjem. Stoga je možda malo, još uvijek i zasada, preuranjeno govoriti o zaista suvremenoj nastavi.

Nakon ovog istraživanja zasigurno je ostavljen prostor za provedbu novih istraživanja i na većem uzorku ispitanika, uz smjernicu da se u budućnosti više pažnje posvećuje ovoj tematici. Očekuje se da će nova istraživanja, zbog doprinosa novog kurikula, u budućnosti pokazati pozitivnije rezultate u smislu učestalijeg provođenja istraživačkog pristupa u nastavi Prirode i društva, ali i općenito o suvremenijoj nastavi. S obzirom na to da je pojam istraživačkog pristupa relativno nov u hrvatskom kurikulu, potrebno je određeno vrijeme, ali i dodatno educiranje učitelja u vidu raznih oblika stručnog usavršavanja, a i kako bi se kao oblik suvremene nastave, koji donosi novi nastavni kurikul u potpunosti implementirao u nastavu Prirode i društva, i učinio je bogatijom i poticajnijom za učenika. 
Ovaj rad je financiralo Sveučilište u Rijeci u sklopu projekta Povezanost s prirodom, organizacija slobodnog vremena djece rane školske dobi i digitalne tehnologije (br. uniri-pr-drustv-19-19 1500) (http://www.ufri.uniri.hr/files/ znanstveni\%20projekti/dunja_andjic_projekt.pdf).

\section{LITERATURA}

1. Alagić, A. (2021). Odgojno-obrazovni efekti istraživačkog rada u nastavi metodike okoline. Društvene i humanističke studije: časopis Filozofskog fakulteta u Tuzli. 11(11), 283-296. https://www.ceeol.com/ search/article-detail?id=875407

2. Anđić, D., Alagić, A. i Pavlović, M. (2020). "School gardens are the best places where pupils can connect with nature and real life, which is one of the key roles of education" - teachers' attitudes about the use of school gardens in learning and teaching at school. U L. Gómez Chova, A. López Martínez i I. Candel Torres (ur.), ICERI 2020 Proceedings, 13th annual International Conference of Education, Research and Innovation Dates, Valencia, Spain: IATED Academy, 2020. 14581467. https://www.bib.irb.hr/1101891

3. Anđić, D., Pejić Papak, P. i Mezak, J. (2020). How to foster a significant connectedness with nature in children through the quality organization of children's leisure time and the use of ict in school? U L. Gómez Chova, A. López Martínez i I. Candel Torres (ur.), EDULEARN20 Proceedings, 12th International Conference on Education and New Learning Technologies, Sevilla, Spain: IATED Academy, 2020. 06210629. https://www.bib.irb.hr/1077684

4. Banchi, H. i Bell, R. (2008). The Many Levels of Inquiry. Science and Children, 46(2), 26-29. https://eric.ed.gov/?id=EJ815766

5. Bayram, Z., Özyalçın Oskay, Ö., Erdem, E., Dinçol Özgür, S. i Şen, S. (2013). Effect of Inquiry based Learning Method on Students' Motivation. Procedia - Social and Behavioral Science. 106, 988-996. https://cyberleninka.org/article/n/209177/viewer

6. Bognar, B. (2004). Poticanje kreativnosti u školskim uvjetima. Napredak, 145(3), 269-283. https://www.bib.irb.hr/665999

7. Bognar, B. (2011). Problemi u ostvarivanju suštinskih promjena u praksi učitelja posredstvom akcijskih istraživanja. U D. Kovačević i R. Ozorlić Dominić (ur.), Akcijsko istraživanje i profesionalni razvoj učitelja i nastavnika (str. 41-60). Agencija za odgoj i obrazovanje. https:// www.bib.irb.hr/558793

8. Bognar, L. i Matijević, M. (2002). Didaktika. Školska knjiga.

9. Boras, M. (2009). Suvremeni pristupi nastavi prirode i društva. Život $i$ škola, LV(21), 40-49. https://hrcak.srce.hr/37079 
10. Borić, E., Škugor, A. i Perković, I. (2010). Samoprocjena učitelja o izvanučioničkoj istraživačkoj nastavi prirode i društva. Odgojne znanosti, 12(2), 361-371. https://hrcak.srce.hr/68278

11. Harlen, W. i Allende, J. E. (2009). Teacher Professional Development in Pre-Secondary School Inquiry-Based Science Education (IBSE). Fundación para Estudios Biomédicos Avanzados. https://www.interacademies.org/sites/default/files/resource/forproject/teachersced.pdf

12. Jensen, E. (2003). Super nastava-nastavne strategije za kvalitetnu školu. Educa.

13. Kurikulum nastavnog predmeta Priroda i društvo za osnovnu školu. (2019). Ministarstvo znanosti i obrazovanja.

14. Lalović, Z. (2009). Naša škola: Metode učenja/nastave u školi. Zavod za školstvo.

15. Letina, A. (2012). Kompetencije učitelja primarnoga obrazovanja za djelotvornu organizaciju i izvođenje nastave prirode i društva. Život $i$ škola, LIX(29), 341-356. https://hrcak.srce.hr/121414

16. Letina, A. (2015). Učestalost primjene konstruktivističkih pristupa učenju u nastavi prirode i društva. Život $i$ škola, LXI(2), 157-168. https:// hrcak.srce.hr/162165

17. Letina, (2016). Effectiveness of Inquiry-Based Science and Social Studies Teaching in the Development of Students' Scientific Competence. Croatian Journal of Education, 18(3), 665-696. https:// hrcak.srce.hr/167971

18. Letina, A. (2019). Factors Influencing the Frequency of Use of InquiryBased Approach to Teaching Primary Science. Croatian Journal of Education, 21(Sp. Ed. 1), 153-166. https://hrcak.srce.hr/229370

19. Letina, A. (2020). Development of Students' Learning to Learn Competence in Primary Science. Education sciences, 10(11), 1-14. https://www.bib.irb.hr/1090182

20. Löfgren, R., Schoultz, J, Hultman, G. i Björklund, L. (2013). Exploratory talk in science education: inquiry-based learning and communicative approach in primary school. journal of baltic science education. Journal of Baltic Science Education, 12(4), 482-496. https://www. researchgate.net/publication/287246558_Exploratory_talk_in_science_education_Inquiry-based_learning_and_communicative_approach_in_primary_school

21. Maguire, M. i Delahunt, B. (2017). Doing a thematic analysis: A practical, step-by-step guide for learning and teaching scholars. Reflections, Journeys and Case Studies, 9(3), 3351-3365. https://ojs.aishe.org/index.php/aishe-j/article/view/335

22. Milne, I. (2010). Sense of Wonder, arising from Aesthetic Experiences, should be the Starting Point for Inquiry in Primary Science. Science 
Education International, 21(2), 102-115. http://www.icaseonline.net/ sei/june2010/p4_ian.pdf

23. Nastavni plan i program za osnovnu školu (2006). Ministarstvo znanosti, obrazovanja i sporta.

24. Nikčević-Milković, A. (2004). Aktivno učenje na visokoškolskoj razini. Život i škola, L(12), 47-54. https://hrcak.srce.hr/index. php?show $=$ clanak\&id_clanak_jezik $=40234$

25. Odluka o donošenju kurikuluma za nastavni predmet Prirode i društva za osnovne škole u Republici Hrvatskoj (2019). Ministarstvo znanosti i obrazovanja.

26. Omerović, M. i Džaferagić-Franca, A. (2011). Aktivno učenje u osnovnoj školi. Metodički obzori, 7(14), 167-181. https://hrcak.srce.hr/78852

27. Pavin, T., Rijavec, M. i Miljević-Riđički, R. (2005). Percepcija kvalitete obrazovanja učitelja nastavnika i nekih aspekata učiteljske i nastavničke profesije iz perspektive osnovnoškolskih učitelja i nastavnika. U V. Vizek Vidović (ur.), Cjeloživotno obrazovanje učitelja i nastavnika: višestruke perspektive (str. 95-124). IDIZ.

28. Pečar, M., Anđić, D., Hergan, I., Skribe Dimec, D. i Pavlin, J. (2020). How to encourage children's connectedness to nature by outdoor learning of children in croatian and slovenian schools? U L. A. Gómez Chova, A. López Martínez i I. Candel Torres (ur.), EDULEARN20 Proceedings, 12th International Conference on Education and New Learning Technologies (str. 714-723). IATED Academy in Sevilla, Spain. https://www.bib.irb.hr/1077690

29. Perković Krijan, I. (2016). Povijesni pregled ideje i potrebe za istraživačkim pristupom u nastavi. Život i škola, 62(3), 77-85.

30. https://hrcak.srce.hr/index.php?show=clanak\&id_clanak_jezik $=260318$

31. Perković Krijan, I. (2016). Uloga zadovoljstva i zaokupljenosti poslom učitelja u istraživačkoj nastavi prirode i društva [doktorska disertacija, Sveučilište u Zagrebu]. Učiteljski fakultet u Zagrebu. http://bib.irb.hr/ datoteka/808317.Doktorski_rad_Ivana_Perkovi_Krijan.pdf

32. Perković Krijan, I., Opić, S. i Rijavec, M. (2017). The Role of Pedagogical Content Knowledge and Experience of Elementary School Teachers in the Implementation of Inquiry Teaching. Croatian Journal of Education, 19(3), 117-136. https://doi.org/10.15516/cje.v19i0.2710

33. Princ, M. i Felder, R. (2007). The Many Faces of Inductive Teaching and Learning. Journal of College Science Teaching, 36(5), 14-20. https://www.researchgate.net/publication/239773785_The_Many_ Faces_of_Inductive_Teaching_and_Learning 
34. Pritchard, A. i Woollard, J. (2010). Psychology for the classroom: constructivism and social learning. Psychology for the classroom series. Routledge.

35. Rajić, V. (2019). Teachers as agents of change. U O. Holz, M. Michielsen i M. Benić Županić (ur.), Requirements and Approaches for Contemporary Teacher Training (str. 200-2010). LIT VERLAG $\mathrm{GmbH} \& \mathrm{Co}$. KG Wien.

36. Septi Andrini, V. (2016). The Effectiveness of Inquiry Learning Method to Enhance Students' Learning Outcome: A Theoretical and Empirical Review. Journal of Education and Practice, 7(3), 38-42. https://files. eric.ed.gov/fulltext/EJ1089825.pdf

37. Števanić-Pavelić, M. i Vlasac, I. (2006). Postignuća učenika primjenom različitih metoda i oblika rada u nastavi prirode. Život i škola, LII(15-16), 155-165. https://hrcak.srce.hr/index. php?show=clanak\&id_clanak_jezik $=39482$

38. Vidas, K. (2020). Istraživački pristup u nastavi prirode $i$ društva [diplomski rad, Sveučilište u Rijeci]. Repozitorij Učiteljskog fakulteta u Rijeci. https://urn.nsk.hr/urn:nbn:hr:189:410332 